\title{
Research on: Motivation to Learn English among College Students in Sudan
}

\author{
Ibrahim Abdelrahim Ibrahim Humaida ${ }^{1}$ \\ ${ }^{1}$ Faculty of Arts \& Science-Tabarjal, Aljouf University, King Saudi Arabia \\ Correspondence: Ibrahim Abdelrahim Ibrahim Humaida, PhD, Educational Psycholgy, and Assistant Professor. \\ Faculty of Arts \& Science-Tabarjal, Aljouf University, King Saudi Arabia
}

Received: March 26, 2012 Accepted: April 24, 2012 Online Published: July 2, 2012

doi:10.5539/elt.v5n8p49 URL: http://dx.doi.org/10.5539/elt.v5n8p49

\begin{abstract}
This research was conducted to achieve the following objectives: to examine motivation to learn English language among students of faculty of arts, Islamic University-Sudan, to find out if there were significant statistical differences on motivation scores related to both student level and age. To pursue these objectives, the researcher used the descriptive method and a simple random sample consisted of (40) male students was selected. The scale for measuring motivation was administerd, the collected data were analyzed by using the following statistical tests on (SPSS): T-test for one sample, One-way analysis of variance, and Pearson correlation coefficient. The results indicated that: motivation scores were higher among students, no significant differences were found on motivation attributed to class level, and there was no correlation between motivation and age. At the end of this research, some recommendations and suggestions for future studies were presented.
\end{abstract}

Keywords: motivation, learning English, college students, Sudan

\section{Introduction}

Motivation has been widely accepted by both teachers and researchers as one of the key factors that influence the rate and success of second/foreign language learning. Motivation provides the primary impetus to initiate learning English language and later the driving force to sustain the long and often tedious learning process (locke, E. 1996).

Motivation, among other psychological variables, plays an effective role on academic achievement among students in general and English language learners in particular. Both intrinsic and extrinsic motivation can work as driving force that affect students overall performance (lukmani.Y. M. 1972).

Motivation alone cannot do without actual action and ability. In order to test motivation level among learners; there are many psychometric tools that should be employed so as to guarantee an accurate measurement for motivation.

Many researchers concerned with motivation have conducted several researches and studies. The current research is an attempt to study motivation and its importance in learning.

\subsection{Statement of Research Problem}

It appears from literature and the previous researches carried out on motivation among learners that there are many variables underlying students' motivation to learn English language.

Students, motivation to learn English in Sudan has to do with student's desire to participate in the learning process. But it also concerns the reasons or goals that underlie their involvement or noninvolvement in academic activities. Although students may be equally motivated to perform a task, the sources of their motivation to learn English as a foreign language may differ.

Motivation plays an important part in improving and developing learner's communicative ability, however, in Sudan, there are many English majors who are aspiring to be part of English-speaking community. It might be true that a few of them have such desire ,but the majority of English majors join the English departments because it is easier for them to get a job with a BA in English than in any other specialization.

\subsection{Research Questions}

This present research set the following research questions for testing: 
1-What is the general trend of motivation among the research sample?

2-Is there any significant difference on motivation among English language learners according to class level?

3-Is there any significant correlation between motivation and age?

\subsection{Importance of Research}

This research is of prime importance on account to deal with an

Area of Educational psychology. It is well-known that the research on motivation is expected to be beneficial for both teachers and learners and because of the central importance attached to motivation by practitioners and researchers alike, motivation has been the target of a great deal of research during the past decades.

\subsection{Objectives}

This research aims to achieve the followings:

1-To measure motivation among English language learners at Islamic University-Faculty of Arts.

2-To identify the difference on motivation among students according to class.

3-To test the correlation between motivation and age.

\subsection{Hypotheses}

1-College students were not motivated to learn English.

2-There was significant statistical difference on motivation due to students level (first and fourth).

3-There was significant correlation found between motivation and age.

\subsection{Limitations}

This research is limited by both time and location. It is carried out on undergraduate students at the faculty of arts, Omdurman Islamic university in Sudan in the year 2011.

\subsection{Definition of Research Terms}

Motivation as defined by Richard Clement (2006) is the driving force by which humans achieve their goals.

In psychology, motivation is internal and external factors that stimulate desire and energy in people to be continually interested in and committed to a job, role, or subject, and to exert persistent effort in attaining a goal (Weiner. B. 2000).

\section{Literature Reviews}

Motivation is the driving force by which humans achieve their goals. Motivation is said to be intrinsic or extrinsic. The term is generally used for humans but it can also be used to describe the causes for animal behavior as well. This article refers to human motivation. According to various theories, motivation may be rooted in a basic need to minimize physical pain and maximize pleasure, or it may include specific needs such as eating and resting, or a desired object, goal, state of being, ideal, or it may be attributed to less-apparent reasons such as altruism, selfishness, morality, or avoiding mortality. Conceptually, motivation should not be confused with either volition or optimism. Motivation is related to, but distinct from, emotion (Susan Harter, 1981).

\subsection{What Is Student Motivation?}

Student motivation naturally has to do with students' desire to participate in the learning process. But it also concerns the reasons or goals that underlie their involvement or noninvolvement in academic activities. Although students may be equally motivated to perform a task, the sources of their motivation may differ.

A student who is INTRINSICALLY motivated undertakes an activity "for its own sake, for the enjoyment it provides, the learning it permits, or the feelings of accomplishment it evokes" (Mark Lepper 1988). An EXTRINSICALLY motivated student performs "IN ORDER TO obtain some reward or avoid some punishment external to the activity itself," such as grades, stickers, or teacher approval.

The term MOTIVATION TO LEARN has a slightly different meaning. It is defined by one author as "the meaningfulness, value, and benefits of academic tasks to the learner-regardless of whether or not they are intrinsically interesting" (Hermine Marshall 1987). Another notes that motivation to learn is characterized by long-term, quality involvement in learning and commitment to the process of learning (Carole Ames 1990).

\subsection{What Factors Influence The Development of Students' Motivation?}

According to Jere Brophy (1987) and Deborah Stipec (1988), motivation to learn is a competence acquired "through general experience but stimulated most directly through modeling, communication of expectations, and 
direct instruction or socialization by significant others (especially parents and teachers)."

Factors influence the development of students motivation can be outlined as follows:

1-home environment

2-school-related success and failure.

3-teachers, beliefs about teaching and learning.

4-schoolwide goals, policies and procedures.

5-classroom climate.

\subsection{Advantages of Intrinsic Motivation}

According to J. Candry and J. Chamber (1987), students with an intrinsic motivation have strong desire and more effort than extrinsically motivated students who exert the minimal amount of learning activity to success. Intrinsic motivation amog English language learners is an important agent to overcome challenging and difficult learning tasks.

\subsection{Motivation to Learn English and How Can Be Fostered among Students}

Brophy (1987) pointed out the importance of classroom climate particularly when students feel a sense of affiliation, being valued and respected,consequently, they are more likely apt to engage actively in the learning process.

According to Martin and Midgley (1991), to enhance motivation to learn among students, educational policies should emphasize mastery learning which is a type of learning based on practice through which students shall be able to apply knowledge in the real world.

\subsection{Causes of Poor Motivation among Students and Their Remedies}

What causes lack of motivation to learn in general and English in particular can be summarized as follows:

1-lack of interest in learning.

2- Poor academic aptitude.

3- Dissatisfaction of basic needs.

4- Psychological strain.

5- Parental expectations.

What can be done to help students with poor motivation is through these strategies:

A process called ATTRIBUTION RETRAINING, which involves modeling, socialization, and practice exercises, is sometimes used with discouraged students. The goals of attribution retraining are to help students to (1) concentrate on the tasks rather than becoming distracted by fear of failure; (2) respond to frustration by retracing their steps to find mistakes or figuring out alternative ways of approaching a problem instead of giving up; and (3) attribute their failures to insufficient effort, lack of information, or reliance on ineffective strategies rather than to lack of ability (Brophy 1986).

Other potentially useful strategies include the following: portray effort as investment rather than risk, portray skill development as incremental and domain-specific, focus on mastery (Brophy 1986).

\subsection{Theory of Motivation}

A reward, tangible or intangible, is presented after the occurrence of an action (i.e. behavior) with the intent to cause the behavior to occur again. This is done by associating positive meaning to the behavior. Studies show that if the person receives the reward immediately, the effect is greater, and decreases as duration lengthens. Repetitive action-reward combination can cause the action to become habit. Motivation comes from two sources: oneself, and other people. These two sources are called intrinsic motivation and extrinsic motivation, respectively (Marshall, Hermine1987).

Applying proper motivational techniques can be much harder than it seems. Raffani, Jones(1993) noted that when creating a reward system, it can be easy to reward A, while hoping for B, and in the process, reap harmful effects that can jeopardize your goals.

Other theories of motivation include: Drive reduction theory (Seligman Martin, 1990), Need theory (Maslow, 1970), and Goal-setting theory (Spike Deborah, 1981).

\subsection{Educational Implications of Motivation}

Educational psychologists give motivation special consideration owing to its great significance in learning 
process.

Gardner \& Lambert (1972), argued that motivation in education can have several effects on how students learn and they behave effectively towards different subjects. Motivation leads to increased effort and energy, enhances cognitive process, increases persistence in learning activities, and leads to improved performance.

\subsection{Summary of Related Previous Researches on Motivation}

There were several previous researches on motivation to learn English conducted worldwide:

Richard Clement (2006) assessed Hungarian students' motivation to learn English. He revealed the presence of a relatively classroom motivation.

Boosakorn (1985) surveyed students' motivation for learning English in Malaysia; he found that students expressed a strong desire to learn English.

Shaaban K. A. (2000) examined motivation of Lebanese students to learn English as a foreign language. The findings revealed that female students were more motivated than their male counterparts.

Furthermore, Kris and Kobon (2006) conducted a research in Slovenia regarding students motivation to learn English, the finding explored the relative importance of the different types of motivation.

\section{Research Methodology}

Concerning the research method, the researcher has selected the descriptive method because it is relevant to the present study.

\subsection{The Population}

This research population represents college students in undergraduate stage at Omdurman Islamic university-Sudan, from which the sample was drawn.

\subsection{The Sample}

The selected sample for the current research was drawn randomly comprising (40)male students who are learning English language at faculty of Arts, Islamic university-Sudan. They were selected as follows: level one (3), level three and four (37).

\subsection{Data Collection Device}

The researcher designed a scale for measuring motivation consisting of (15) items with five alternatives for answering (always-often-sometimes-rarely-never). See Appendix 1.

\subsection{Reliability and Validity}

The scale was detected for both reliability and validity as shown on the following table:

Table 1. Shows correlation coefficient for each item on motivation scale

\begin{tabular}{|c|c|c|c|c|c|}
\hline & $\begin{array}{l}\text { Scale Mean if } \\
\text { Item Deleted }\end{array}$ & $\begin{array}{l}\text { Scale Variance if } \\
\text { Item Deleted }\end{array}$ & $\begin{array}{l}\text { Corrected } \\
\text { Item-Total } \\
\text { Correlation }\end{array}$ & $\begin{array}{l}\text { Squared Multiple } \\
\text { Correlation }\end{array}$ & $\begin{array}{l}\text { Cronbach's } \\
\text { Alpha if Item } \\
\text { Deleted }\end{array}$ \\
\hline Q1 & 37.3333 & 33.238 & .075 & . & .303 \\
\hline Q2 & 37.4667 & 35.981 & -.087 & . & .351 \\
\hline Q3 & 36.8667 & 35.981 & -.032 & . & .322 \\
\hline Q4 & 37.8000 & 33.600 & .060 & . & .308 \\
\hline Q5 & 38.0667 & 31.495 & .448 & . & .269 \\
\hline Q6 & 37.8000 & 31.171 & .253 & . & .243 \\
\hline Q7 & 37.2000 & 33.886 & .463 & . & .307 \\
\hline Q8 & 39.1333 & 38.410 & -.260 & . & .390 \\
\hline Q9 & 38.0667 & 29.924 & .182 & . & .257 \\
\hline Q10 & 37.4000 & 34.543 & .024 & . & .318 \\
\hline Q11 & 38.6000 & 28.114 & .312 & . & .197 \\
\hline Q12 & 38.0000 & 30.286 & .201 & . & .252 \\
\hline Q13 & 38.7333 & 30.067 & .182 & . & .258 \\
\hline Q14 & 36.8667 & 36.838 & -.146 & . & .339 \\
\hline Q15 & 38.1333 & 31.695 & .128 & . & .283 \\
\hline
\end{tabular}

The table above indicated correlation coefficients for each items on motivation scale. 
Table 2. Shows Reliability and Validity

\begin{tabular}{lll}
\hline $\begin{array}{l}\text { Cronbach's } \\
\text { Alpha }\end{array}$ & $\begin{array}{l}\text { Cronbach's Alpha Based on total } \\
\text { Items correlation }\end{array}$ & N of Items \\
\hline 0.632 & 0.654 & 15
\end{tabular}

Validity $=0.794$

It appears from the above table the scale is reliable and valid statistically.

\section{Statistical tests used to analyze data}

The researcher used the following statistical tests to verify the research hypotheses:

1-T-test for one sample.

2-One-way analysis of variance.

3-Pearson's correlation coefficient.

\section{Results \& Discussion}

This section of research deals with result obtained for each hypothesis and its interpretation and discussion:

\subsection{Hypothesis 1}

It predicted that English language learners were not motivated to learn.

To verify this hypothesis, the researcher used T-test for one sample as shown on the following table:

Table 3. Shows the result of (t-test)

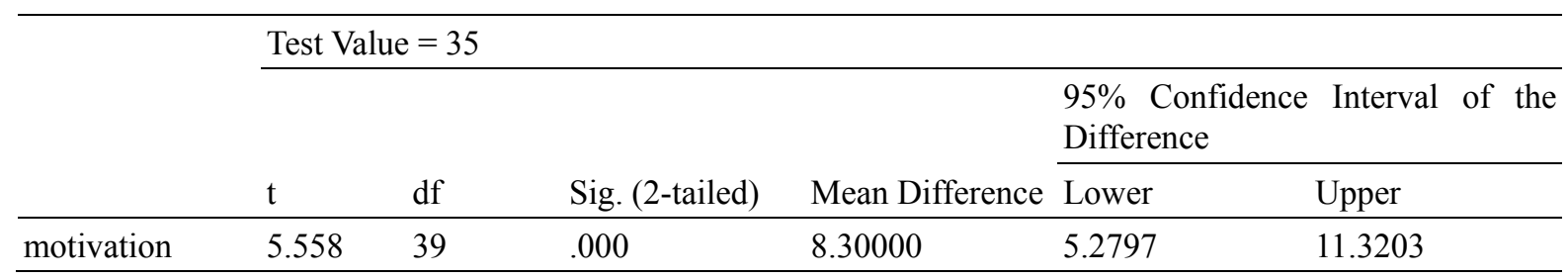

It appears from the tables that mean difference is significant at (.000), this indicates motivation scores are high among the learners.

\section{Discussion}

The result revealed that students, motivation for learning English was high. It can be noticed that this finding was in line with the results of related studies conducted worldwide (Richard Clement, 2006, Boosakorn, 1985, Shaaban, 2000, and Kris, 2006). It was expected owing to the learners, ongoing keenness and desire to learn and master English as foreign language. The popularity of English language might be one of the reasons why English language learners in different parts of the world are well-motivated to that end.

According to researcher, student motivation to learn English in Sudan has to do with student's desire to participate in the learning process. But it also concerns the reasons or goals that underlie their involvement or noninvolvement in academic activities. Although students may be equally motivated to perform a task, the sources of their motivation to learn English as a foreign language may differ.

\subsection{Hypothesis 2}

It speculated that there were significant differences on motivation for learning English owing to class level.

To test this hypothesis, the researcher used one-way analysis of variance as shown on the following table:

Table 4. Shows the result of Analysis of Variance

\begin{tabular}{llllll}
\hline & Sum of Squares & df & Mean Square & F & Sig. \\
\hline Between Groups & 498.724 & 3 & 166.241 & 2.009 & .130 \\
Within Groups & 2979.676 & 36 & 82.769 & & \\
Total & 3478.400 & 39 & & & \\
\hline
\end{tabular}


It appears from the table that no significant difference on motivation due to student level (first and fourth).

Discussion

The result of this hypothesis pointed out no significant statistical differences were found on motivation scores due to class. According to researcher, students or learners are normally found in classrooms and each learner, regardless of his class, is supposed to be an active member in learning process. There are other factors that can contribute effectively to class motivation to learn English such as nature of learners, class environment, and extracurricular activities.

\subsection{Hypothesis 3}

It hypothesized that no correlation found between motivation scores and learners, ages.

To test this hypothesis, the researcher used Pearson's correlation coefficient as displayed on the following table:

Table 5. Shows the result of correlation

\begin{tabular}{llll}
\hline & & motivation & age \\
\hline Motivation & Pearson Correlation & 1 & .108 \\
& Sig. (2-tailed) & & .508 \\
& $\mathrm{~N}$ & 40 & 40 \\
\hline age & Pearson Correlation & .108 & 1 \\
& Sig. (2-tailed) & .508 & \\
& $\mathrm{~N}$ & 40 & 40 \\
\hline
\end{tabular}

It is obvious from the table that no significant correlation between motivation and age.

\section{Discussion}

It seems to the best of researcher's knowledge that motivation to learn cannot be affected by learner's age. That is why -for instance-children have also motivation to learn, and this may give an impression that motivation is a propensity or an instinct.

\section{Conclusion}

This research aimed at examining motivation to learn English among college students at Omdurman Islamic University in Sudan. The results showed that the English learners were instrumentally motivated. Furthermore, the research revealed that there was no significant difference on motivation due to student level, and there was no correlation between motivation to learn and age.

On the other hand, it should be acknowledged that there were some limitations to this research.First, the limited number of the participants might not enhance the generalizability of the findings. Secondly, the selected sample was male students only.

To conclude, what cannot be disputed is the fact that motivation is an important variable when examining successful second language acquisition. It should be realized that making learners recognize a real need to accomplish learning goals and providing them with the motivation to learn is one of the best steps we can take to facilitate effective learning.Thus, future researches in Sudan are needed to shed more light on motivation to learn from different perspectives as only the iceberg has been discovered.

\section{Recommendations}

Based on the results obtained, the researcher recommends the followings:

1-To promote students awareness towards learning process.

2-To keep learners in touch with modern English language teaching methods.

\section{Suggestions for Further Studies}

The researcher suggested the following future researches to be carried out:

1-Motivation for learning English among secondary school students.

2-The effect of motivation on academic achievement among college students. 


\section{References}

Ames, Carole A. (1990). Motivation: What Teachers Need to Know. TEACHERS COLLEGE RECORD, 91, 3(Spring 1990), 409-21.

Boosakorn Vijchulate. (1985). A Survey of students, motivation for learning English. RELC Journal, June, 16, 68-81. http://dx.doi.org/10.1177/003368828501600106

Brophy, Jere. ON MOTIVATING STUDENTS. Occasional Paper No. 101. East Lansing, Michigan: Institute for Research on Teaching, Michigan State University, October 1986. 73 pages. ED 276724.

Condry, J., \& J. Chambers. (1978). Intrinsic Motivation and the Process of Learning. In M. R. Lepper, \& D. Greene (Eds), THE HIDDEN COSTS OF REWARD. Hillsdale, New Jersey: Lawrence Erlbaum Associates, Inc. pp. 61-84.

Diana Cordova, \& Mark Lepper. (1995). Intrinsic Motivation and the Process of Learning: Beneficial Effects of Contextualization, Personalization, and Choice.

Garderner, \& Lambert. (1972). Attitudes and Motivation in Second Language Learning. Rowley, MA: Newbury House.

Kris Kyriacou, \& Machiko Kobon. (2006). Motivation to learn and teach English in Slovenia. Educational Studies, 24, 345-351. http://dx.doi.org/10.1080/0305569980240307

Lepper, Mark R. (1988). Motivational Considerations in the Study of Instruction. COGNITION AND INSTRUCTION, 5(4), 289-309. http://dx.doi.org/10.1207/s1532690xci0504_3

Locke, E. (1996). Motivation through Conscious Goal Setting. Applied and Preventive Psychology, 5, 117-123. http://dx.doi.org/10.1016/S0962-1849(96)80005-9

Lukmani, Y. M. (1972). Motivation to Learn Language Proficiency. Language Learning, 22, 261-273. http://dx.doi.org/10.1111/j.1467-1770.1972.tb00087.x

Maehr, Martin L., \& Carol Midgley. (1991). Enhancing Student Motivation: A Schoolwide Approach. EDUCATIONAL PSYCHOLOGIST, $26(3$ \& 4), 399-427.

Marshall, Hermine H. (1987). Motivational Strategies of Three Fifth-Grade Teachers. THE ELEMENTARY SCHOOL JOURNAL, 88, 2(November), 135-50. EJ 362747.

Maslow, A. H. Motivation and Personality. New York: Harper \& Row.

Raffini, James. (1993). WINNERS WITHOUT LOSERS: STRUCTURES AND STRATEGIES FOR INCREASING STUDENT MOTIVATION TO LEARN. Boston: Allyn and Bacon. p. 286.

Richard Clement. (2006). Motivation, Self-confidence, and Group Cohesion in the Foreign Language Classroom. Language Learning, 44, 417-448.

Seligman, Martin E. P. (1990). Motivation. New York: Alfred A. Knopf, Inc. p. 101. ISBN 0-394-57915-1.

Shaaban, K. A., \& Ghaith. G. (2000). Student motivation to learn English as a foreign language. Foreign Language Annals, 33, 632-644.

Stipek, Deborah. (1988). MOTIVATION TO LEARN: FROM THEORY TO PRACTICE. Englewood Cliffs, New Jersey: Prentice Hall. p. 178.

Susan Harter. (1981). A New Self-Report Scale of Intrinsic versus Extrinsic Orientation in the Classroom: Motivational and Informational Components.

Weiner, B. (2000). Interpersonal and Intrapersonal theories of motivation from an attributional perspective. Educational Psychology Review, 12, 1-14. http://dx.doi.org/10.1023/A:1009017532121 


\section{Appendix 1. Motivation Scale as designed by researcher}

\begin{tabular}{|c|c|c|c|c|c|c|}
\hline & Item & Always & Often & Sometimes & Rarely & Never \\
\hline 1 & $\begin{array}{l}\text { I learn English because it is the } \\
\text { language of sciences }\end{array}$ & & & & & \\
\hline 2 & $\begin{array}{l}\text { I learn English because it is the } \\
\text { key for getting a job }\end{array}$ & & & & & \\
\hline 3 & $\begin{array}{l}\text { I learn English as the others } \\
\text { respect me more }\end{array}$ & & & & & \\
\hline 4 & $\begin{array}{l}\text { I learn English to converse with } \\
\text { varied people }\end{array}$ & & & & & \\
\hline 5 & $\begin{array}{l}\text { I learn English to be more at ease } \\
\text { with English speaker }\end{array}$ & & & & & \\
\hline 6 & $\begin{array}{l}\text { I learn English to participate more } \\
\text { freely in the activities of other } \\
\text { cultural groups }\end{array}$ & & & & & \\
\hline 7 & $\begin{array}{l}\text { I learn English to become more } \\
\text { knowledgeable }\end{array}$ & & & & & \\
\hline 8 & $\begin{array}{l}\text { I learn English because our } \\
\text { religion urges us to learn the } \\
\text { others' languages }\end{array}$ & & & & & \\
\hline 9 & $\begin{array}{l}\text { Learning English enables me to } \\
\text { express my opinion }\end{array}$ & & & & & \\
\hline 10 & $\begin{array}{l}\text { I learn English to understand the } \\
\text { habits of English speaking people }\end{array}$ & & & & & \\
\hline 11 & $\begin{array}{l}\text { I learn English to help me browse } \\
\text { some English websites }\end{array}$ & & & & & \\
\hline 12 & $\begin{array}{l}\text { I learn English because it is the } \\
\text { most dominant international } \\
\text { language }\end{array}$ & & & & & \\
\hline 13 & $\begin{array}{l}\text { Learning English helps me use the } \\
\text { computer programmes }\end{array}$ & & & & & \\
\hline 14 & $\begin{array}{l}\text { I learn English to join higher } \\
\text { education aboard }\end{array}$ & & & & & \\
\hline 15 & $\begin{array}{l}\text { I learn English to enjoy linguistic } \\
\text { skills }\end{array}$ & & & & & \\
\hline
\end{tabular}

